\title{
The Role of the Constitutional Council of the Republic of Kazakhstan on Human Rights
}

\author{
Abylassimov Murager Nastaevich ${ }^{1} \&$ Musin Kuat Saniyazdanovich ${ }^{1}$ \\ ${ }^{1}$ Department of constitutional and international law, Karaganda State University named after Evnei Arystanovich \\ Buketov, Karaganda, Kazakhstan \\ Correspondence: Abylassimov Murager Nastaevich, Department of constitutional and international law, \\ Karaganda State University named after Evnei Arystanovich Buketov, Karaganda, Kazakhstan. E-mail: \\ serstam@mail.ru
}

Received: April 8, 2015 Accepted: May 19, 2015 Online Published: June 13, 2015

doi:10.5539/ass.v11n16p315 URL: http://dx.doi.org/10.5539/ass.v11n16p315

\begin{abstract}
Solving the problem of the human rights is not only referred to enlarging of range of human being and citizen rights and freedoms, but also set in the Constitution of the Kazakhstan, or strengthening their guarantees. In fact the problem concerns considerable renovation of the whole concept of human being, citizen rights, duties and the practice of their constitutional realization. It is extremely important in the course of such process to take into account both intergovernmental and international aspects of the problem stipulated by the character of the researched problem.

One of the important legal guarantees in securing human, citizen rights and freedoms in the Republic of Kazakhstan is the Constitutional Council, set up in accordance with the new Constitution and which is an independent state entity to provide acting regime of constitutional legitimacy. In order to carry out its main task the Constitutional Council must defend and secure human, citizen rights and freedoms, set in the Constitution, thus proving constitutional legitimacy regime.

First in its history the newly adopted legislation gives enforcement powers to the Constitution of the Republic of Kazakhstan. It is the very positive fact. Such function is stipulated by the juridical nature of the Constitutional Council and effective constitutional supervision on human rights and freedoms are not possible without it.

The Constitutional Council activity linked with consideration of laws passed by the Parliament in terms of their compliance with the Constitution is very important to secure human, citizen rights and freedoms. It is the Constitutional Council power to consider how laws adopted by the Parliament comply with the Constitution from above mentioned position.
\end{abstract}

Keywords: kinds and functions of the constitutional control, protection of the rights of citizens, the decision and the decision of the constitutional council of Republic Kazakhstan

\section{Introduction}

Special place in the constitutional values occupy human rights and freedoms. The constitutions of many countries fix them as the highest values, establish the obligation of the State to respect and protect them. Body of constitutional control of the Republic of Kazakhstan, ensuring supremacy of the Constitution throughout the country is - the Constitutional Council. Constitutional Council of the Republic of Kazakhstan for its normative acts creates applicable laws and regulations, and promotes coordinated interaction on constitutional branches of government; strengthen the rule of law and the constitutional protection of constitutionally guaranteed rights and freedoms of man and citizen.

President of the Constitutional Council of the Republic of Kazakhstan Rogov I. I. argues that a special role in the protection of human rights carries the Constitutional Council. Within the framework of the constitutional control it is an effective guarantor of the country's legislation functioning and, ultimately, and enforcement within the content of the constitutional provisions. In a globalized world where every phenomenon gets through worldwide communication assessment and analysis of virtually anywhere in the world, before the totality of national and international law enforcement systems, including constitutional justice, a number of new tasks. Protection of migrants' rights, the definition of the relation of rights and freedoms of residents and non-residents in the 
economic and financial sphere, the responsibility of transnational organizations to workers - citizens activities, environmental rights - Here is a list of issues which are faced with increasing speed national human rights protection system . Phenomenon of a different order serves the global fight against terrorism, drug trafficking, environmental pollution, etc., which requires certain restrictions previously 'untouchable' rights and freedoms (Rogov, 2011).

In this regard, at the forefront of events is often exactly Constitutional Control, which has to solve: how radically new or updated public relations in its legal regulations meet constitutional requirements.

The Constitutional Council is composed of seven members whose term lasts six years. Life members of the Constitutional Council are rightly ex-Presidents of the Republic. President of the Constitutional Council shall be appointed by the President of the Republic, and in the case of a tie, his vote is decisive. Two members of the Constitutional Council are appointed by the President of the Republic, two members appointed by the Senate and the Majilis respectively. Half of the members of the Constitutional Council shall be renewed every three years.

Adopted by popular vote August 30, 1995 Kazakhstan's Constitution reflected the will of the people and set an important beginning of the democratic government, fundamental rights and freedoms of man and citizen, the original provisions of the new economic order. Consistent implementation of the constitutional provisions is absolutely essential for the functioning of all public institutions and, consequently, for the normal existence of the entire state. The Constitution of the Republic of Kazakhstan stipulates that the man, his life, rights and freedoms are the supreme values of the state, they belong to everyone from birth, be recognized as absolute and inalienable, determine the content and application of laws and other regulations. Exercise of the rights and freedoms of man and citizen shall not violate the rights and freedoms of other persons, infringe on the constitutional order and public morality (Articles 1 and 12) (The Republic Kazakhstan constitution 2008). The Constitution of the Republic of Kazakhstan requires lawmakers to come primarily from these norms and put at the forefront of human rights.

The Concept of Legal Policy of the Republic of Kazakhstan for the period from 2010 to 2020, approved by the Decree of the Head of State on August 24, 2009, noted that one of the important mechanisms for the regime of constitutional legality, the accurate interpretation of the principles and norms of the Constitution, the formation of the development of national guidelines and law enforcement practice is to increase the efficiency of the Constitutional Council and the practical implementation of its comprehensive regulatory decisions in the legal policy of the state (The Concepts of legal policy of Republic Kazakhstan for the period with 2010 till 2020, 2009).

Its normative decrees and messages are intended to provide a correct interpretation of the principles and norms of the Constitution of the different actors of social relations, which is a guarantee of sustained and stable development of the country. Legal position of the Constitutional Council is in favor of orienting factors in the development of the current legislation and the formation of law enforcement.

\section{Methodology}

This research use general and individual methods of scientific inquiry, in particular such methods as dialectics. The dialectics method based on revealing of a problem of protection connected in sphere of the rights of citizens (in particular, in work are considered a role of the Constitutional Council of Republic Kazakhstan).

\section{Overview of the Issues and the Problems}

Certainly improve the efficiency of execution of final decisions of the Constitutional Council largely contribute to such consultative and advisory bodies as the Secretariat of the Security Council and the Council for Legal Policy under the President of the Republic of Kazakhstan.

Would also like to point to the example of the functions of protecting the rights and freedom of the bodies of the constitutional jurisdiction of foreign countries through the use of three basic forms of their activity: through abstract, concrete and individual control of the conformity of the constitution and the rights contained therein and freedoms of man and citizen of laws and other regulations as well as judicial and administrative decisions.

Abstract control provides the possibility of filing a request with the Constitutional Court on the constitutionality of adopted laws and other normative acts, regardless of their application in specific legal relationships. The purpose of this type of control - compliance legislator constitution and its provisions governing the rights and freedoms of individuals in decision- legal acts (Austria, France). This type of control operates in the countries with a centralized system of constitutional control, when only a specialized constitutional court may abstractly, without regard to the application of this rule to implement it in the context of the interpretation of constitutional provisions. In order to abstract control of the constitutionality of laws Constitutional Court resolves legislator 
possible violations of human rights and freedoms. Such control is mainly used in civil law countries (Austria, Germany, Italy, Spain, Portugal, etc.).

Specific control, sometimes referred to as the incident, provides that the question of the constitutionality of the applicable law was considered and solved only in connection with the particular litigation. The most widely used this kind of control in countries with a decentralized system of constitutional review, where all the courts are competent to decide the constitutionality of the applicable rules of law. Specific control also operates in a number of civil law countries, where there is a centralized system of constitutional control exercised by specialized bodies quasi-judicial nature. Centralized system comes from the fact that the courts of general jurisdiction do not exercise control over the compliance of regulatory legal acts of the constitution. Here the general courts can only raise the question of the constitutionality of regulations before the constitutional court as a query with regard to the particular court case and only within these limits to ensure compliance with the law of the constitution (Italy, Austria, Germany, etc.) (Amandykova, 2002).

Constitutional control is carried out in the form of individual or collective complaints, which includes empowering the individual - the subject of human rights and freedoms, as well as various associations of citizens, legal persons are entitled to file a complaint with the Constitutional Court on violations of their rights and freedoms, laws, regulations, judicial decisions. Constitutional complaint acts as an important legal remedy individual from arbitrary government.

During the activity the Constitutional Council made more than 140 regulatory decisions, where are the official interpretation of the constitutional provisions on human rights and freedoms, independence and sovereign rights of States, territorial integrity and inviolability of borders and inalienable territory of the unitary state and the presidential form of government and many other, all were subject to the provisions of the constitutional review of 73 articles of the Basic Law.

According to some of the famous scholars in the field of constitutional law Amandykovoy C. To: "By applying the follow-up given the opportunity to correct the error legislator correct legal practice. However, we are only talking about the elements of subsequent constitutional because the courts have the right to appeal to the Constitutional Council has just about the laws and regulations that they believe infringe on the rights and freedoms of man and citizen. Therefore, the jurisdiction of the Constitutional Council applies only to one group of laws and regulatory acts, which are regulated by a circle of relations connected with fixed constitutional rights and freedoms of man and citizen" (Zhailganova, 2011).

The Constitutional Council is empowered to determine the order of execution of its decisions. State bodies and officials shall within the period prescribed by the Board, to inform him of the measures taken in response to its decision (The Performance of the President of Republic Kazakhstan of N. A. Nazarbayev at extraordinary VII congress of Republican political party "Otan", 2004).

President of the Republic, while appreciating the work of the Constitutional Council, noted that Kazakhstan's model of constitutional control, as shown, has proved itself (Lazarev, 2002). In order to further strengthen the capacity of the Constitutional Council for the Protection of the Basic Law in 2007 at the initiative of the Head of State was made an addition to the Constitution, providing for checks on the constitutionality of decisions of the Parliament and its Chambers.

The impact of decisions of the Constitutional Council on the rulemaking process takes many forms. Often in acts of the Constitutional Council draws attention to the subjects of legislative initiative certain aspects of legal regulation requiring legislative action, which subsequently included in the plan of legislative activity of the Government.

Thus, the Government of the Republic of Kazakhstan dated April 16, 2008 №355 approved the Comprehensive Plan of measures to bring the current law into conformity with the Constitution of the Republic of Kazakhstan, which includes a number of measures to implement the recommendations of the Constitutional Council, set out in its annual resolutions and letters of constitutional legality in the country. In the development of the Government decisions, changes and additions to the Rules of the Government of the Republic of Kazakhstan, according to which the formation of the current and future plans of lawmaking activities of the Government shall be based on the provisions of the regulatory decisions of the Constitutional Council.

Execution of decisions of the Constitutional Council is a barometer of law. Rightly stated in the legal literature, that if the body of constitutional decisions are not executed or executed improperly, then torpedoed goal towards which they are directed - the protection of the constitutional order, fundamental rights and freedoms of man and 
citizen, the rule of the Constitution (The standard resolution of the Constitutional Council of Republic Kazakhstan from November, 2009).

It should be particularly emphasized the important role of the Constitutional Council in the development and improvement of the judiciary, prosecutors and other law enforcement agencies, as well as in the development of criminal procedural law. It is in the actions and writings of the Constitutional Council stated positions, which are then included in the legislation as the principles of the criminal justice division of procedural functions of providing qualified legal assistance, the right to judicial protection and equality of the parties before the court, guaranteeing the right to appeal to the court decisions taken in the pre-trial proceedings and the decisions taken by the trial court to the higher court, and many others.

In order to implement the legal positions of the Constitutional Council of the Republic of Parliament and other government agencies of the country changes and amendments to existing laws and other normative legal acts of the Republic.

In legal practice also implemented conclusions annual messages of the Constitutional Council on the constitutional legality in the Republic to improve the existing legislation. In annual messages Constitutional Council often draws attention to the need for parliamentarians to improve the legal system of the Republic, the adoption of new standards align with the Basic Law and the decisions of the Constitutional Council of the Republic of existing law.

Developing constitutional provisions protecting the rights and freedoms of citizens of the Republic of Kazakhstan national courts and law enforcement institutions, the Constitutional Council in its decision of 7 May 2001 № 6/2 " On the representation of the Kyzylorda Regional Court declared unconstitutional the second part of paragraph 6.12 of Article 6 of the Treaty rental complex "Baikonur", articles 5 and 11 of the Agreement on Cooperation between law enforcement agencies in maintaining law and order on the territory of" Baikonur " set a number of basic items that were perceived as fully authorized state bodies of the Republic . In this decision the Constitutional Council pointed out that the extension of jurisdiction of the Russian Federation on the territory of Kazakhstan and its citizens violates the provisions of the Constitution, violates the sovereignty of Kazakhstan, the implementation of prosecution and justice for the citizens of the Republic of Kazakhstan by Russian law enforcement and judicial authorities detracts from the constitutional powers of courts, as well as special the inquiry and investigation and prosecution of Kazakhstan. As a result, the conditions for unconstitutional activities on the territory of other state bodies. Their work involves the application of coercive measures of complex criminal and administrative measures that infringe on the fundamental rights, freedoms and legitimate interests of citizens (application of preventive measures, the production of searches, seizures and other investigative actions, assignment and enforcement of sentences). In the process of bringing into conformity with the Constitution and the decision of the Constitutional Council of 7 May 2001 № 6/2 of the provisions of interstate agreements on complex "Baikonur", between the Governments of the Republic of Kazakhstan and the Russian Federation, October 3, 2006 signed a protocol on amendments and additions to the specified treaties and agreements, according to which citizens of the Republic of Kazakhstan, the offense committed on the territory of "Baikonur" complex will be sent to law enforcement agencies of the Republic of Kazakhstan.

The Constitution of the Republic of Kazakhstan formulates constitutional and legal principles of rights and freedoms. They relate both to government actions and behavior of citizens. Principles that obligation to respect and ensure the state are substantial: human rights and freedoms are directly applicable, should not be issued laws that abrogate or infringe the rights and freedoms set; regulations affecting the rights, freedoms and duties of a citizen of the Republic of Kazakhstan, must be published; enshrined in the Constitution of the Republic of Kazakhstan rights and freedoms determine the content and application of laws and other regulations. Strict for citizens is a principle: the rights and freedoms must not violate the rights and freedoms of others. Marked feature of the constitutional law of the Republic of Kazakhstan, securing rights and freedoms, but does not guarantee the implementation of relevant norms in life. Their implementation depends on many political, economic and social factors, on the effectiveness of legal guarantees.

And one of the important legal guarantees of human rights and freedoms in general is a citizen of Kazakhstan the Constitutional Council of the Republic of Kazakhstan, the main purpose of which is to, providing a regime of constitutional law in the society, to protect and safeguard the rights and freedoms of man and citizen, enshrined in the Constitution.

\section{Conclusion}

Constitutional control as important social and public functions, providing the dynamic development of the social system and internal stability is directly related to the nature, the character of social relations, the principles and 
objectives laid down in the framework of the Constitution. Almost all countries have sought to formulate a constitutional nature of their social relations, describing the state as secular or legal, democratic or social. Determining the nature of social relations also involves refinement approaches and priorities formation of the institutional system of the state and the definition of the internal logic of its functioning. In this sense, particular importance is attached to work on identifying the nature of social relations, of their constitutional consolidation and development of mechanisms to guarantee their control.

The decision of the Constitutional Council is a significant source of Kazakhstan's constitutional rights. A number of features can be attributed to the legal acts. Legal validity of decisions of the Constitutional Council did not differ according to their content. They are characterized by universal validity and in accordance with the provisions of the 1995 Constitution - finally.

The competence of the Constitutional Council is designed in such a way as to maximize benefits combined preand post, as well as abstract and concrete forms of constitutional review. Extension of the Constitutional Council, as well as improve its performance, as evidenced by the opinions of Kazakh scientists have contributed to the following measures: consolidate and build on particular activities to comply with the Constitution in the area of unity and separation of powers, the functioning of higher state bodies in the sphere of human rights and freedoms of man and citizen; constructively autonomized functions and activities of the Constitutional Council, courts and prosecutors' offices, and the use of resources of the Institute of constitutional review to strengthen the judiciary and vice versa; maximally eliminate the factor of politicization of the members of the Constitutional Council and the excess of its powers; gradually as the development of civil society and the state, to carry out capacity building of the Constitutional Council by expanding its powers and access to the institution of constitutional control.

Constitutional control appears not to say the legislature and the executive, that they should cancel each other out, not only it is the main purpose for which there is constitutional, if the main purpose of the constitution - the protection of human rights, and the main purpose of the constitutional control, providing including separation of powers, - ensure the protection of human rights. So do not absolute legal state institutions as a means of forgetting their main goal. Otherwise degenerate basic democratic orientation of constitutional development, it becomes, in fact, in its opposite.

\section{References}

Amandykova, S. K. (2002). Formation of the constitutionalism doctrine in Kazakhstan (p. 384).

Lazarev, L. (2002). Execution of decisions of the Constitutional Court of Byelorussia. The Russian justice, 9(17).

Rogov, I. I. (2011). Performance of the Chairman of the Constitutional Council of Republic Kazakhstan. International conference Protection of human rights by bodies of the constitutional justice: Possibilities and problems of individual access, Ukraine, Kiev. Retrieved September, 16, 2011, from http://www.constcouncil.kz

The Concepts of legal policy of Republic Kazakhstan for the period with 2010 till 2020 the Decree of the President of Republic Kazakhstan. Retrieved August, 24, 2009, from http://referats.urist-center.ru/referat/ content-517.html

The Performance of the President of Republic Kazakhstan of N. A. Nazarbayev at extraordinary VII congress of Republican political party "Otan". Retrieved June, 15, 2004, from http://www.zakon.kz/4447257-rol-kon stitucionnogo-soveta-v.html

The Republic Kazakhstan constitution (p. 44). (2008).

The standard resolution of the Constitutional Council of Republic Kazakhstan from November. About official interpretation of rates of clause 4 of the Constitution of Republic Kazakhstan with reference to an order of execution of decisions of the international organizations' and their bodies. Retrieved from http://www.constcouncil.kz/rus/resheniya?cid=11\&rid=533

Zhailganova, A. N. (2011). Performance of a member of the Constitutional Council of Republic Kazakhstan At the international conference devoted to the 15 anniversary of the Constitutional Court of Republic Armenia. Legal consequences of decisions of the Constitutional Court in constitutionalism strengthening in the country. Retrieved from http://www.constcouncil.kz/

\section{Copyrights}

Copyright for this article is retained by the author(s), with first publication rights granted to the journal.

This is an open-access article distributed under the terms and conditions of the Creative Commons Attribution license (http://creativecommons.org/licenses/by/3.0/). 